\title{
Roman Kwiecień*
}

\section{THE COURT OF JUSTICE, THE NATIONAL COURTS AND THE CONTROVERSY OVER THE 'ULTIMATE ARBITER' OF THE CONSTITUTIONALITY OF LAW IN THE EUROPEAN UNION}

\begin{abstract}
The paper addresses the issue of a judicial forum entitled to resolve conflicts between European Union law and national constitutional rules. First and foremost, the issue is discussed under the old primacy/supremacy of EU law controversy. The author seeks to answer whether the national law, including constitutional rules, of a Member State can be ineffective owing to being contradictory to EU law. If so, by whom can national laws be held ineffective? In other words, which of the two judicial fora (national and European) have the last word in these conflicts or who is the ultimate arbiter of the constitutionality of law within the European legal space? The author argues that legal reasoning should reconcile, on the one hand, the specificity of the EU's unique legal order and effective application of its provisions and, on the other hand, the international legal status of the Member States and their constitutions. This approach leads to the conclusion that there is no ultimate judicial arbiter within the European legal space.
\end{abstract}

Keywords: European Union law primacy, ultimate arbiter of constitutionality, European Union constitution, Court of Justice of the European Union, national constitutions, national constitutional courts

* Professor, Faculty of Law and Administration, Jagiellonian University in Kraków, ORCID ID: 0000-0003-0831-9203 


\section{Introduction}

The case Marbury v. Madison of 1803 before the US Supreme Court ${ }^{1}$ is commonly seen as a leading milestone on the road to what is called 'constitutionalism'. Notwithstanding the silence of the US Constitution on the judicial review of legislation enacted by the US Congress, the Chief Justice Marshall, finding a conflict between a statute enacted by the Congress and the Constitution, considered it "the essence of judicial duty" to follow the Constitution. This approach underlines the supremacy of the supreme law of the land over legislative and executive bodies and their acts. As such, it supports the idea of the rule of law that says that all laws, even those made by sovereign powers, are subject to fundamental law, which is sometimes labelled as 'sovereignty of law'.

The idea of constitutionalism, crucial for systems which accept a judicial review of legislation, promotes the fundamental significance of the constitution or equivalent constitutional principles, which entitles the courts to set aside even the laws enacted by democratic legislatures. Can this pattern be applied to the relationship between European Union law and national laws of the Member States? The Member States and the European Union (EU) are obliged under Article 4(3) of the Treaty on the European Union (TEU) ${ }^{3}$, pursuant to the principle of sincere cooperation, "in full mutual respect, assist each other in carrying out tasks which flow from the Treaties. The Member States shall take any appropriate measure, general or particular, to ensure fulfilment of the obligations arising out of the Treaties or resulting from the acts of the institutions of the Union. The Member States shall facilitate the achievement of the Union's tasks and refrain from any measure which could jeopardise the attainment of the Union's objectives". Is it only the Court of Justice of the European Union (CJEU) that performs the role of a constitutional judicial body in the legal space created by the EU institutions and the Member States? The CJEU ensures that in the interpretation and application of the European Treaties, the law is observed (Article19(1) TEU). But what about the conflicts between national constitutional rules and EU law during its interpretation and application? Can the national law, including constitutional rules,

1 Marbury v. Madison, 5 US (1 Cranch) 136 (1803).

2 F.G. Jacobs, The Sovereignty of Law. The European Way, CUP, Cambridge 2007, pp. 5-8.

3 OJ C 326, 26.10.2012. 
of a Member State be ineffective owing to being contradictory to EU law? If so, by whom can national laws be held ineffective? In other words, which of the two judicial fora (national and European) have the last word in conflicts between European and national constitutional rules, or who is the ultimate arbiter of the constitutionality of law within the European legal space?

The issue of a constitutional position of EU law within the legal orders of the Member States is as old as European legal studies. Today, each textbook of EU law devotes one or more chapters to the principles of the direct effects, effectiveness, primacy/supremacy and autonomy of this legal order. These principles are not just often studied subjects; they are also used to as defining characteristics of EU law, and they serve as an underpinning for the overall doctrine of European law as an alleged autonomous legal order. This especially concerns the principles of direct effect and primacy. As Bruno De Witte claims, "EU law is now often presented as being unique because it is endowed with direct effect and primacy". Is this really true? De Witte himself has some doubts about this. The question will be discussed below. Anyway, the primacy principle together with the principles of direct effect and of uniform applicability are believed to constitute not only the foundation of effectiveness of the European Union legal order but also play the role of the pillars of an unofficial European Constitution. The primacy principle is even seen as the embodiment of an actual transfer of constitutional power to Europe. ${ }^{5}$

A jeopardy to the primacy, direct effect, effectiveness of European law and, consequently, the success of the European legal project is generated by the mentioned conflict regarding the 'arbiter of constitutionality in Europe'. This conflict has arisen due to the lack of unconditional acceptance of the primacy/supremacy of Community/EU law over national laws by the most important national judicial agencies. It is necessary to remember, as Alec Stone Sweet puts it, that some of the most important achievements of legal integration are rooted not in cooperation but in authority conflicts between the Luxembourg Court and national constitutional and supreme

4 B. De Witte, Direct Effect, Primacy and the Nature of the Legal Order, [in:] P. Craig, G. De Búrca (eds.), 'The Evolution of EU Law', 2nd ed., OUP 2011, p. 361.

5 See J.H.H. Weiler, Un „Europa Cristiana“. Un Saggio Esplorativo, Polish translation: J.H.H. Weiler, Chrześcijańska Europa. Konstytucyjny Imperializm czy Wielokulturowość?, W Drodze, Poznań 2003, pp. 102-104; J.H.H. Weiler, In Defense of the Status Quo: Europe's Constitutional Sonderweg, [in:] J.H.H. Weiler \& M. Wind (eds.), 'European Constitutionalism Beyond the State', CUP, Cambridge 2003, pp. 7-8. 
courts. ${ }^{6}$ This is why the primacy/supremacy and arbiter of constitutionality issues are dependent upon one another and should be addressed together.

The role of the CJEU in giving prominence to the primacy principle of Community/EU law cannot be overestimated, as this role is simply crucial for the European legal project. The Rome Treaties of 1957 established the Communities, which were transformed into the 'constitutionalised' communities by a series of seminal judgments of the Luxembourg Court. It is not accidental that the judgments in the van Gend \& Loos and Costa/E.N.E.L. cases denote the real origin of the Community legal order, and the CJEU itself is seen as a body which brought about 'the juridical Coup d'Etat'. There is at least one more reason why we should discuss the CJEU case law, which is perhaps the most important for legal reasoning. The issue concerns the justification of the principle of primacy: is it set in the constitutions of EU Member States, international law (these two sources are emphasised by the national courts) or does it stem from the specific and unique nature of the legal order of the EU? As known, the latter view has been presented in the CJEU case law. Therefore, the CJEU's and national courts' stands should be compared with each other. Although the interpretation of the primacy principle given by the CJEU did not raise any controversy in some EU Member States, in others, however, especially in France, Germany, Italy, Denmark, Poland, Spain and the UK, the unconditional primacy of Community/EU law has been rejected by the main judicial bodies. The relationship between the primacy principle of EU law and provisions of national constitutions that emphasise the supremacy of the national constitutional principles still remains ambiguous. The conclusions derived from the decisions of the national constitutional courts can support working out the 'strategy of prevention' towards conflicts over the constitutionality of law in Europe. A one-sided approach to the primacy principle, i.e. an approach based either on in dubio pro communitate or in dubio pro republicae principles, unjustifiably challenges

6 A. Stone Sweet, The Judicial Construction of Europe, OUP, Oxford 2004, p. 81.

7 See J.H.H. Weiler, The Transformation of Europe, 'Yale Law Journal' 1991, p. 2403; J.H.H. Weiler \& A. von Bogdandy, Doctrine of Principles, 'Jean Monnet Working Paper' 2003 9/03, p. 41, http://jeanmonnetprogram.org/papers/03/030901-01.pdf; A. Stone Sweet, The Juridical Coup d'État and the Problem of Authority, 'German Law Journal' 2007 no. 10, pp. 924-927; A. Stone Sweet, The European Court of Justice, [in:] P. Craig, G. De Búrca (eds.), supra note 4, pp. 128-133. On the CJEU's role as a political actor within the European integration project, see K.J. Alter, The European Court's Political Power. Selected Essays, OUP, Oxford 2009, pp. 92-108. 
the significance of some of the legal orders and runs the risk of being accused of arbitrariness. As such, it can enhance the controversy on the 'final arbiter of constitutionality' in the European Union, and consequently, it can shake the utility of the European integration project. The controversy seems to be crucial for this project, because it concerns a question as to whether it is the national constitutional courts or the CJEU which ultimately determines the relationship between national constitutional provisions and EU law. These issues will be discussed in parts II-IV of the paper. Part V deals with the interpretation of the primacy principle and the 'ultimate arbiter' issue in the light of the international legal status of the EU Member States. I argue that the two principles embed in the TEU, namely, the principle of conferred competencies (Articles 5 (1-2), 4(1)) and the principle of national identity connected with the political and constitutional structure of a Member State (Article 4(2)), shape the interpretation of both the primacy principle and the controversy on 'arbiter of constitutionality'. This interpretation should reconcile, on the one hand, the specificity of the Union's unique legal order and effective application of its provisions and, on the other hand, the international legal status of the Member States and their constitutions. But this approach leads to a rather pessimistic conclusion, namely - there is no a final judicial arbiter within the European legal space.

\section{The Primacy of Community/EU Law and the Court of Justice}

The primacy of Community/EU law over the national law of EC/EU Member States was recognised by the CJEU as one of the constitutive principles of the Community legal order long before the endeavour to confirm the principle in the Treaty of 29 October 2004 establishing a Constitution for Europe. The Constitutional Treaty itself was supposed to be a step forward on the way towards European legal monism.

Article I- 6 of the Constitutional Treaty stated: "The Constitution and law adopted by the institutions of the Union in exercising competences conferred on it shall have primacy over the law of the Member States." The inclusion of this principle in Title I, Part I of the Treaty emphasised its constitutive significance for the EU legal order. From this standpoint, it was recognised as reinforcing the position of the primacy principle in comparison with its role as an unwritten principle of primary Community 
law. ${ }^{8}$ Besides, the Declaration of Intergovernmental Conference stated: "The Conference notes that the provisions of Article I- 6 reflect existing Court of Justice case law." Three years later when the European Council decided to return the Constitutional Treaty into a de-constitutionalised 'reform treaty', the primacy principle was again removed from the text of the founding Treaties, but a new and much longer Declaration was adopted and attached to the Lisbon Treaty. It reads as follows:

"The Conference recalls that, in accordance with the well-settled case law of the Court of Justice of the European Union, the Treaties and the law adopted by the Union on the basis of the Treaties have primacy over the law of Member States, under the conditions laid down by the said case law.

The Conference has also decided to attach as an Annex to this Final Act the Opinion of the Council Legal Service on the primacy of EC law as set out in 11197/07 (JUR)."

The mentioned Opinion states inter alia that:

"The primacy of EC law is a cornerstone principle of Community law. According to the Court, this principle is inherent to the specific nature of the European Community. [...] The fact that the principle of primacy will not be included in the future treaty shall not in any way change the existence of the principle and the existing case-law of the Court of Justice."

Indeed, this fact does not and will not "in any way change the existence of the principle and the existing case-law of the Court of Justice". A similar view was adopted e.g. by the Spanish Tribunal Constitucional and the French Conseil Constitutionnel in their judgments on the Constitutional

8 See M. Kumm \& V. Ferreres Comella, The Future of Constitutional Conflict in the European Union: Constitutional Supremacy after the Constitutional Treaty, 'Jean Monnet Working Paper' 5/04, pp. 8-10, http://www.jeanmonnetprogram.org/ papers/04/040501-15.pdf; M. Kumm \& V. Ferreres Comella, The Primacy Clause of the Constitutional Treaty and the Future of Constitutional Conflict in the European Union, 'ICON' 2005, vol. 3, p. 473. The author if this paper put forth a different view. See R. Kwiecien, The Primacy of European Union Law over National Law under the Constitutional Treaty, 'German Law Journal. Special Issue - Unity of the European Constitution' 2005, no. 11, p. 1479. See also F.C. Mayer, Supremacy lost? - Comment on Roman Kwiecień, 'German Law Journal. Special Issue - Unity of the European Constitution’ 2005 , no. 11, p. 1497.

9 Declaration (no. 17) concerning primacy, attached to the Final Act of the Treaty of Lisbon, [2008] OJ C115/344. 
Treaty. ${ }^{10}$ The primacy clause in the Constitutional Treaty (Article I-6), in the view of those courts, did not alter the nature of the Union or the scope of the primacy principle. In particular, the Conseil Constitutionnel concluded that the Constitutional Treaty was just an international treaty, and its title was of no constitutional significance. ${ }^{11}$ Both courts made a conceptual distinction between supremacy and primacy, with supremacy being the concept attributed to the national constitution as the supreme law of the State within the hierarchy of norms, whereas primacy simply describes the fact that European law takes precedence over national law. This standpoint was seen as a useful and positive attitude towards the primacy issue. ${ }^{12}$

The two terms - primacy and supremacy-are often used interchangeably, at least in English language literature. It should be remembered, however, that the Court of Justice has not used the term supremacy, unlike e.g. the German Federal Constitutional Court and the Polish Constitutional Tribunal, which is quite symptomatic. Strictly speaking, the term supremacy has appeared only once in the judgments of the CJEU so far. ${ }^{13}$ The issue of differences between those terms will be addressed below.

10 Tribunal Constitutional, case 6603/2004, Declaration 1/2004; Conseil Constitutionnel, Decision no. 2004-505 DC of 19.11.2004, Traité établissant une Constitution pour l'Europe, Journal officiel No. 273, 19885. See discussion M. Kumm \& V. Ferreres Comella, supra note 8. Conseil Constitutionnel underlined in its decision: "[L]'article I-6 du traité (establishing a Constitution for Europe - R.K.) soumis à l'examen du Conseil n'implique pas de revision de la constitution" (para. 13). At the same time, one needs to remember that the Conseil denied primacy of provisions of EU law which were inconsistent with express and specific provisions of the French Constitution. See Decision no. 2004-498 DC of 29.7.2004, Journal officiel du 7 août 2004, 14077. Conseil stated: "[L]a transposition en droit interne d'une directive communautaire résulte d'une exigence à laquelle, il ne pourrait être fait obstacle qu'en raison d'une disposition expresse contraire de la Constitution" (para. 4).

11 For critical comment on this Decision, see Editorial, A Pre-emptive Strike from the Palais Royal, 'European Law Review' 2005, vol. 30, p. 1; F.C. Mayer, Europarecht als französisches Verfassungsrecht, 'Europarecht' 2004, no. 6, pp. 925-936.

12 F.C. Mayer, supra note 8, p. 92.

13 Walt Wilhelm et al. v. Bundeskartellamt, Case no. 14/68, Judgment of the Court of 13.2.1969, ECLI:EU:C:1969:4, para. 5 (English special edition): “Article 87(2)(e) [the EEC Treaty - R.K.], in conferring on a Community institution the power to determine the relationship between national laws and the Community rules on competition, confirm the supremacy of Community law". The French language version of the judgment says on "le caractère prééminent du droit communautaire". 
Three principal arguments in the CJEU case law can be seen as motivations for the primacy of Community/EU law: 1) the international legal obligation to observe treaties; 2) ensuring the efficacy and uniform application of Community law; 3) the autonomous/unique character of the Community legal order.

In the relatively little-known decision on the Humblet case, ${ }^{14}$ the CJEU saw the pacta sunt servanda principle connected with ratification of the EEC Treaty as a reason for the primacy of Community law over national law. The Court took a similar stance in the San Michele case. ${ }^{15}$

A threshold judgment that distinguished between the Community legal order and the traditional international legal order was, in the general opinion, one adjudicated in the Van Gend \&Loos case. ${ }^{16}$ The Luxembourg Court recognised in it the EEC Treaty as "a new quality in the international legal order". A year later, and what is probably the best known judgment in this context, in the Costa v. E.N.E.L. case, ${ }^{17}$ the Court went a step further and, while speaking of the primacy of the Community legal order, termed it as its "own legal system" and underlined its "special and original nature". This judgment also answered the question of a direct conflict between Community law and national law, stating that in case of conflict, the former prevails. This is the second argument of the Court for the primacy of European law: its unique and autonomous nature.

The third argument in the CJEU case law for the primacy of European law is the efficacy and uniform application of its provisions. In the judgment on the Walt Wilhelm case, ${ }^{18}$ apart from stressing the distinctive nature of the legal system stemming from the EEC Treaty, the Court observed that "it would be contrary to the nature of such a system to allow Member

14 Humblet v. Belgian State, Case 6/60, Judgment of the Court of 16.12.1960, ECLI:EU:C:1960:48. On the importance of this decision, see B. De Witte,"Retour à Costa". La primauté du droit communautaire à lumière du droit internationale, 'Revue Trimestrielle de Droit Européen' 1984, no. 20, pp. 425, 426-7; J. Wouters, National Constitutions and the European Union, 'Legal Issues of Economic Integration' 2000, no. 27, pp. 25, 68.

15 The Order of the Court of 22.6.1965, Acciaierie San Michele SpA v. High Authority of the ECSC, Case 9/65, ECLI:EU:C:1968:10 (English special edition).

16 Van Gend \& Loos, Case 26/62, Judgment of the Court of 5.2.1963, ECLI:EU:C:1963:1 (English special edition).

17 Flaminio Costa v. E.N.E.L, Case 6/64, Judgment of the Court of 15.7.1964, ECLI:EU:C:1964:66.

18 Walt Wilhelm et al. v. Bundeskartellamt, Case 14/68, Judgment of the Court of 13.2.1969, ECLI:EU:C:1969:4, para. 6. As mentioned, that is the only judgment of the ECJ where the Court used the term supremacy instead of primacy. 
States to introduce or to retain measures capable of prejudicing the practical effectiveness of the Treaty". Effectiveness as an argument for primacy is certainly not a new one, because it provides a traditional motivation for the primacy of international law obligations over national law. In the Simmenthal SpA case ${ }^{19}$, the CJEU went a step further and stressed that, in accordance with the principle of primacy of Community law, the provisions of domestic law that run counter to it are automatically inapplicable. Community law - the Court argued - is "an integral part of [...] the legal order applicable in the territory of each of the Member States", and Community law provisions "by their entrance into force render automatically inapplicable any conflicting provision of current national law" ${ }^{20}$ In this way, the Court of Justice has underlined what is often known as a duty to disapply national law. ${ }^{21}$ But disapplication is only a minimum requirement. The primacy principle further excludes, in the CJEU's opinion, the possibility of enacting by the Member State any new legislation that runs counter to Community law. Otherwise, this might lead to the "denial of the effectiveness of obligations undertaken unconditionally and irrevocably by Member States pursuant to the Treaty and would thus imperil the very foundations of the Community". ${ }^{22}$ One can share an opinion claiming that the Luxemburg Court's primary or traditional view of primacy has been a rather pragmatic one. ${ }^{23}$ The Court of Justice requires only, due to effectiveness of European law, non-application of the inconsistent national rule, not its invalidity. This point inclines to choose a proper concept supremacy or primacy? The term supremacy more than primacy implies the hierarchy of legal sources and norms, as well as the issue of their validity/ invalidity. As such, it has real constitutional consequences. This is why

19 Amministrazione delle Finanze dello Stato v. Simmenthal SpA, Case 106/77, Judgment of the Court of 9.3.1978, ECLI:EU:C:1978:49, paras. 17, 18.

20 Simmenthal SpA, supra note 19, paras. 3, 21.

21 This standpoint was reaffirmed later by the Court. See The Queen v Secretary of State for Transport, ex parte Factortame and Others, Case C-213/89, Judgment of the Court of 19.6.1990, ECLI:EU:C:1990:257, para. 20; Nimz v City of Hamburg, Case C-184/89, Judgment of the Court (Sixth Chamber) of 7.2.1991, ECLI:EU:C:1991:50; Krzysztof Filipiak v. Naczelnik Izby Skarbowej w Poznaniu, Case C-314/08, Judgment of the Court (Third Chamber) of 19.11.2009, ECLI:EU:C:2009:719.

22 Simmenthal SpA, supra note 19, para. 18. See also Liselotte Hauer v. Land Rheinland-Pfalz, Case 44/79, Judgment of the Court of 13.12.1979, , ECLI:EU:C:1979:290, para. 14.

${ }^{23}$ B. De Witte, supra note 4, p. 341. 
the term primacy is better than supremacy, because the Court has never touched the validity of national law and has never pointed to any kind of hierarchy of norms between Community/EU law and national law. ${ }^{24}$ Nonetheless, as the Court upheld in the Costa case, Community law "cannot be overridden by domestic legal provisions, however framed". ${ }^{25}$

The primacy principle under the reasoning of the CJEU results in the following obligations of Member States: 1) the prohibition on national agencies to challenge the validity of Community/EU law; 2) the prohibition to apply national provisions that are contrary to Community/EU provisions; 3) the prohibition to enact provisions that are contrary to Community/ EU provisions; and 4) the obligation to remove national legislation that is contrary to Community/EU law. According to the Court, the last duty is justified, because the binding force of national provisions contrary to Community/EU regulations, even if these provisions are not actually applied, would, in the Court's view, create a condition of uncertainty for citizens undertaking actions in law. ${ }^{26}$

There is another aspect of the CJEU's view of primacy which could be called 'procedural' or 'structural' primacy. ${ }^{27}$ The Court in the Brasserie $d u$ Pêcheur/Factortame case held that there should be a provision for State liability where national legislature was responsible for a breach in Community law, whereas such liability for legislative acts was unknown to many national legal systems. ${ }^{28}$ The same can be said as far as judicial power is concerned. In the Gerhard Köbler case of 2003, the CJEU stated that a Member State could be held liable under European law for misapplication

24 F.C. Mayer, supra note 8, 89. In the Filipiak case (supra note 21), the CJEU stated: Pursuant to the principle of primacy of Community law, a conflict between a provision of national law and a directly applicable provision of the Treaty is to be resolved by a national court applying Community law, if necessary by refusing to apply the conflicting national provision, and not by a declaration that the national provision is invalid, the powers of authorities, courts and tribunals in that regard being a matter to be determined by each Member State [para. 82].

25 Flaminio Costa v. E.N.E.L., supra note 17, 1141 ('droit communautaire ne peut se voir opposer de norme interne quelle qu'elle soit' Recueil 1160).

${ }^{26}$ Commission v. France, Case 167/73, Judgment of the Court of 4.4.1974, ECLI:EU:C:1974:35, paras. 41-42.

27 B. De Witte, supra note 4, p. 343. De Witte recognises it as the prevailing approach in French language literature, ibidem, p. 343, note 74.

28 Brasserie du Pêcheur v Germany and The Queen v Secretary of State for Transport, ex parte Factortame, Cases C-46/93 and C-48/93, Judgment of the Court of 5.3.1996, ECLI:EU:C:1996:79. 
of its provisions by the national courts of last instance. ${ }^{29}$ This issue does touch upon the constitutional aspect. According to the CJEU, when misapplying national rules is taken into account, national courts can 'set aside' constitutional norms defining their jurisdiction or their powers in relation to other State authorities. ${ }^{30}$ Thus, the national courts in this case were simply invited to assume new jurisdictional powers and create, in fact, a new law rather than choose between two applicable national norms. One can argue that the CJEU recognised itself here as the final arbiter of constitutionality of law within the multilevel European legal order. The Court simply recognised its own role as an important reason for primacy of European law in this order because this role supports the unique character of the European legal order.

According to the Court, the ultimate grounds for primacy are rather pragmatic considerations, namely, the creation of a sine qua non condition for the existence of the European Union legal order. ${ }^{31}$ In other words, the primacy of European law has been, for the CJEU, a necessary condition for direct effect of its provisions, their effectiveness and their uniform application in all Member States. One can say that those are uniform application of European law and its effectiveness that are the reasons for primacy, while the primacy doctrine justifies the legitimacy of European law. As Franz Mayer puts it, the primacy doctrine gives the legal constructs established to explain the position motivated by reasons, i.e. uniform application and effectiveness. ${ }^{32}$

Nonetheless, the CJEU's claims on the autonomy and independence of European law created by the EEC Treaty, which was, according to the Court, an 'independent source of law' and established an 'own legal system' which had 'special and original nature', prompt one to ask the question of whether the primacy of European law can be convincingly argued on grounds other than those stemming from international law.

Recognition of the autonomy and unique character of European law denotes that this law does not derive its justification either from international law or from the legal orders of the Member States - it

29 Gerhard Köbler v. Republik Österrich, Case C-224/01, Judgment of the Court of 30.9.2003, ECLI:EU:C:2003:513.

30 The Queen v Secretary of State for Transport, ex parte Factortame and Others, Case C-213/89, Judgment of the Court of 19.6.1990, ECLI:EU:C:1990:257.

31 J. Wouters, supra note 14, p. 67.

32 F. Mayer, supra note 8, pp. 93-94. 
validates its importance by own unique features. Autonomy constitutes a fundamental condition that, in the view of the CJEU and some scholars enables constitutionalisation of European law, at least in the functional sense, i.e. as a set of principles investing their legal subjects with rights and obligations independent of others. ${ }^{33}$ Critical comment on the issue is needed.

Although the CJEU has emphasised the autonomous and unique nature of EU law in many better or less-known judgments, it has not, however, offered any broader theoretical explanations for its meaning. The CJEU has simply treated the autonomy of EU law axiomatically. ${ }^{34}$ From the autonomy of the European legal order, the Court has inferred two significant consequences: 1) the validity of European law can be judged exclusively in the light of this law and remains the exclusive competence of an EU court; and 2) the constitutions of the Member States cannot prejudice the primacy of European law. ${ }^{35}$

There are, however, good reasons for challenging the autonomy of EU law in such a sense in which the autonomy of the national legal order is understood. It is fitting to speak of the interpretative and valid autonomy of European law (with the CJEU remaining its upholder), yet objections might be raised as to the view of the substantive, procedural and institutional autonomy of this law, i.e. autonomy characteristic of a legal order that does not derive its validity from another legal order. ${ }^{36}$ The 'European monism' presented by the CJEU does not reflect the situation

33 See e.g. N. MacCormick, Questionning Sovereignty: Law, State and Nation in the European Commonwealth, OUP, Oxford 1999, pp. 97-122; N. MacCormick, The New European Constitution. Legal and Philosophical Perspective, Biuro Trybunału Konstytucyjnego, Warsaw 2003, pp. 42-44. MacCormick does not, however, exclude international law as the normative basis of EU law. See also studies by J.H.H. Weiler in note 5 and J.H.H Weiler \& U.R. Haltern, Autonomy of the Community Legal Order - Through the Looking Glass, 'Harvard International Law Journal' 1996, vol. 37, p. 411.

34 See J. Boulouis, R.M. Chevallier, Grands Arrêts de la Cour de Justice des Communautes Européennes, $6^{\text {th }}$ ed., t. I, Dalloz-Sirey, Paris 1994, p. 140; J.Wouters, supra note 14, p. 25.

35 See especially Internationale Handelsgesellschaft $\mathrm{mbH}$ v. Einfuhr-und Vorratsstelle für Getreide und Futtermittel, Case 11/70, Judgment of the Court of 17.12.1970, ECLI:EU:C:1970:114, para. 3; Foto-Frost v. Hauptzollamt Lübeck-Ost, Case 314/85, Judgment of the Court of 22.10.1987, ECLI:EU:C:1987:452, paras. 11-16; Winner Wetten, Case C-409/06, Judgment of the Court (Grand Chamber) of 8.9.2010, ECLI:EU:C:2010:503, para. 61; Stefano Melloni v. Ministerio Fiscal, Case C-399/11, ECLI:EU:C:2013:107, para. 59.

${ }^{36}$ See T. Schilling, The Autonomy of the Community Legal Order: An Analysis of Possible Foundations, 'Harvard International Law Journal' 1996, vol. 37, p. 389. 
de lege lata. It is contradicted by substantive borrowings by EU law from the constitutions of the Member States and numerous references to them. ${ }^{37}$ The position of the Member States as 'the masters of the Treaties' is also still unquestionable. The mutual agreement of States or the international legal paradigm continues to be a major justification for the EU legal order, as it is not an 'European society (demos)' but the Member States that remain the primary source of European powers . For this reason, it was not a convincing argument that the presence of the written primacy principle in EU primary law (the former Constitutional Treaty of 2004) denoted the recognition by the Member States and their courts of this law as one that self-justifies its primacy. ${ }^{38}$ What is perhaps more important is that the national constitutional and supreme courts have strongly objected to the landscape of European monism supported by the Luxembourg Court.

\section{The Primacy of Community/EU Law and the National Courts}

The objections from the national constitutional and supreme courts against unconditional acceptance of the primacy of Community/EU law concern essentially two matters: 1 ) the relationship between constitutional principles, including fundamental rights protected therein, and Community/ EU law; and 2) delimitation and sources of EU competences.

The primacy of Community/EU law, both primary and secondary, in relation to the infra-constitutional (statutory) law of the Member States has been widely accepted by the national courts, even despite the treatment of Community norms as 'infra-constitutional'. ${ }^{39}$ Nonetheless, there was

37 E.g. J. Wouters, supra note 14, p. 34, speaks of "the large dependence of EU law on national constitutional law: without constitutional arrangements in the Member States there cannot be a European legal order".

38 The argument is advanced by A. Albi \& P. van Elsuwege, The EU Constitution, National Constitutions and Sovereignty: An Assessment of a "European Constitutional Order", 'European Law Review' 2004, vol. 29, p. 741, 751. Also see e.g. the decisions of Conseil Constitutionnel, supra notes 10-11, in particular Décision no. 2004-505 DC, Traité établissant une Constitution pour l'Europe, where Conseil Constitutionnel concluded that the Constitutional Treaty was an international treaty, and its title was of no constitutional significance.

39 See e.g. the judgment of the Spanish Constitutional Court, Electoral Law Constitutionality case (1991) [in:] A. Oppenheimer (eds.), 'The Relationship Between 
a difference between the courts of the old Member States and the new ones. For the former, the Costa judgment may have come as a surprise, while for the latter, the primacy doctrine was a firmly established and widely accepted characteristic of the Community legal order. As Bruno de Witte explains it:

"For them, unlike for the original Six, primacy did not require ex post constitutional creativity but was a matter of voluntary acceptance as part of the acquis communautaire. [...] One would therefore expect the principle of primacy to be part of the terms of accession, and recognition of primacy to be part of constitutional preparations for membership."

The decisions of the Polish Constitutional Tribunal before joining the EU clearly indicated an amicable legal interpretation towards the process of European integration. In the judgment of 27.5.2003, it stated: "[Constitutionally correct and preferable is such interpretation of the law that serves to implement the constitutional principle of favouring the process of European integration and cooperation between States". ${ }^{41}$

In the opinion of the national courts, the relationship between a European norm and a national norm cannot be explained within the rule of lex posterior derogat legi priori. Thus, in this area, the national courts have accepted the pragmatic approach of the CJEU. Nonetheless, there have been two essential differences between them and the CJEU. The first divergence between them emerged relating to the justification and legal grounds for the primacy of Community law. Unlike the CJEU, the national courts comparatively seldom justified primacy by the autonomy of the European legal order. If the issue of autonomy of European Union law was raised in the judgments of national courts, this argument underwent a substantial international legal and constitutional modification. The second source of judicial controversy concerns the primacy over national constitutional law. This is a matter on which there is not a consensus either between the CJEU and national courts, or across all EU Member States.

European Community Law and National Law: The Cases', vol. I [hereafter: Oppenheimer I], Cambridge University Press 1994, pp. 702, 704-705.

40 B. De Witte, supra note 4, pp. 349-350. See also analysis of the political, social and historical context in which the CJEU has been embedded, and why the Member States have accepted its standpoint, K.J. Alter, supra note 7, pp. 123-128.

41 Case K 11/03, OTK-A 5/2003, para. III.16. 
The foundations for the primacy of Community/EU law were seen by the national courts in the "specific nature of international treaty law", as a "result of the ratification of the EEC Treaty" and in the emergence of a "new legal order which has been inserted into the municipal legal order", ${ }^{33}$ or even "by virtue of partial cession of sovereignty". ${ }^{44}$ Most often, however, the courts indicated the consent of the State constitution or the accord of the national sovereign. This is especially characteristic of the case law of the courts in Germany, ${ }^{45}$ France, ${ }^{46}$ Italy, ${ }^{47}$ Greece, ${ }^{48}$ Portugal ${ }^{49}$, Poland ${ }^{50}$

42 See the "Le Ski" case (1971), Belgium, Cour de Cassation, Minister for Economic Affairs v. SA Fromagerie Franco-Suisse, Oppenheimer I, pp. 245, 266; Luxemburg, Conseil d'Etat, Bellion et al. v. Minister for the Civil Service, Oppenheimer I, pp. 668, 670.

43 Germany, BVerfG, Alfons Lütticke GmbH, BVerfGE 31, 145.

44 Spain, Supreme Court, Canary Islands Custom Regulation, Oppenheimer I, pp. 694, 697; Ireland, Supreme Court, Crotty v. An Taoiseach et al., Oppenheimer I, pp. 599, 603 (opinion of Judge Finlay).

45 BVerfG, Internationale Handelsgesellschaft mbH v. Einfuhr - und Vorratsstelle für Getreide und Futtermittel (Solange I) (1974), BVerfGE 37, 271; BVerfG, Wünsche Handelsgesellschaft (Solange II) (1986), BVerfG 73, 339; BVerfG, Kloppenburg (1987), BVerfG 75, 223.The Bundesverfassungsgericht spoke of the "unwritten rule of primacy of Community law which has been inserted into the municipal legal order by laws approving the Community Treaties taken in conjunction with Article 24 (1) of the Basic Law".

46 Cour de Cassation, Administration des Contributions Indirects et Comité Interprofessionel des Vins Doux Naturels v. Ramel case (1970), Oppenheimer I, p. 279, 283. The court gave those acts of secondary Community law "the force of international treaties"; Cour de Cassation, Administration des Douanes v. Société Cafés Jacques Vabre et Weigel et Compagnie case (1975), Oppenheimer I, pp. 287, 309-310. Regarding the EEC Treaty, the court waived the requirement of reciprocity applied to other international agreements on account of the Treaty's established own procedure of dispute settlement in the event of failure to observe its provisions; Conseil d'Etat, Nicolo case (1989), Oppenheimer I, p. 335. See also Decision no. 2004-496 DC of Conseil Constitutionnel, Loi pour la confiance dans l'économie numérique, case of 10.6.2004. The Conseil Constitutionnel recognised in its decision that implementation of directives in the French legal system was based on the constitutional approval; Decision no. 2007-560 DC of 20.12.2007. The Conseil underlined that it was an amendment of the Constitution that established a necessary condition for the ratification of the Lisbon Treaty (paras. 9-10, 34).

47 Constitutional Court, Frontini v. Ministero Delle Finanze case (1973), Oppenheimer I, pp. 629, 634; Constitutional Court, Spa Grantial v. Amministrazione delle Finanze dello Stato case (1984), Oppenheimer I, pp. 642, 646-647.

48 Council of State, Banana Market case (1984), Oppenheimer I, pp. 576, 578; Council of State, Mineral Rights Discrimination case (1986), Oppenheimer I, pp. 581, 582; Council of State, Karella v. Minister of Industry case (1989), Oppenheimer I, pp. 584, 586.

49 Court of Appeal of Coimbra, Cadima case (1986), Oppenheimer I, pp. 675, 679.

50 European Arrest Warrant case of 27.4.2005 (P 1/05), OTK ZU 42/A/2005; Accession Treaty case of 11.5.2005 (K 18/04), OTK ZU 5/A/2005, item 49; Lisbon Treaty case 
and the UK ${ }^{51}$. The national courts thus have rejected the hierarchy of legal acts, within which the acts of national law, including the constitutions, are subject to the supremacy of Community/EU law. Having adopted the dualist paradigm of explaining the relationship between national law and Community/EU law, the national courts derive the binding force of this law from the constitutional principle of observance of international law in good faith rather than from the distinctive nature of the European legal order and its autonomy. Two important consequences follow therefrom. First, the courts and other State agencies are constitutionally obliged to apply Community law, because failure to observe this constitutes a constitutional tort. ${ }^{52}$ Second, national legal acts do not automatically cease to be valid because they are inconsistent with European law. ${ }^{53}$ They are repealed in accordance with national legislative procedures. This is a matter to be determined by each Member State, which is now also confirmed by the CJEU. ${ }^{54}$

Another clear manifestation of the temperate approach of the national courts to Community/EU law is simply jealous protection of the supremacy of national constitutional law. This manifests itself as early as at the stage of ratification of the treaties creating the primary law of the EC/EU. During the ratification process, the national courts examine the legitimacy of EU primary law under the constitutional provisions concerning the exercise of national sovereignty and constitutionally protected rights. ${ }^{55}$ An adverse

of 24.11.2010 (K 32/09), OTK ZU 9/A/2010, item 108. For comments see e.g. K. KowalikBańczyk, Should We Polish It Up? The Polish Constitutional Tribunal and the Idea of Supremacy of EU Law, 'German Law Journal' 2005, no. 10, p. 1356.

51 House of Lords, Factortame LTD v. Secretary of State for Transport case (1990) [judgment of Lord Bridge of Harwich], Oppenheimer I, pp. 882, 883.

52 See e.g. Kloppenburg case, supra note 45 and the judgments of the Polish Constitutional Tribunal, supra note 50.

$53 \quad$ See e.g. Spa Grantial case, supra note 47.

54 See Filipiak case, supra note 24.

55 See e.g. the decision of the Irish Supreme Court, Crotty case, supra note 44, p. 600-603; the decision of BVerfG Maastricht Treaty 1992 Constitutionality case (1993), BVerfGE 89, 155; the decisions of the French Conseil Constitutionnel, European Communities Amendment Treaty case (1970), Oppenheimer I, p. 276; Treaty on European Union (Maastricht I) case (1992), Oppenheimer I, p. 385; Treaty on European Union (Maastricht II) case (1992), Oppenheimer I, p. 399; Treaty establishing a Constitution for Europe case (2004), supra note 10; the decision of the Danish Supreme Court, Carlsen et al. v. Rasmussen case (1998), [in:] A. Oppenheimer (eds.), 'The Relationship Between European Community Law and National Law: The Cases', vol. II, Cambridge University Press 2003 [hereafter: Oppenheimer II], p. 175. In this context, of importance are also 
judgment on this issue prompted constitutional amendments, whose objective was to create the legal grounds for ratification of the European treaties and implementation of secondary sources of European law. ${ }^{56}$ One can claim that constitutional entitlement does matter.

The protection of supremacy of the national constitution manifests itself even stronger in the national constitutional courts' emphasis of their role as guardians protecting the basic law against the constitutionally unfounded actions of international agencies and legal acts made by them. In this way, they recognise themselves as the final arbiter of constitutionality within the national legal space. It is the national constitutional courts that use, unlike the CJEU, the term supremacy in this context. The basic principles of national legal orders and fundamental human rights present in the national constitutions set up the limit to the unconditional acceptance of the primacy of EU law. Although an open conflict between the CJEU and the national constitutional courts has not occurred, the constitutional courts have shown a clear tendency to emphasise their autonomy in the national legal order and thereby not to recognise the CJEU as 'the arbiter of constitutionality in Europe. ${ }^{57}$ Well known are the conditional reservations of the constitutional courts regarding a potential refusal to apply European law in the event it does not meet the requirements and criteria for constitutionality. ${ }^{58}$ Moreover, the national constitutional courts

British decisions on account of the principle of Parliamentary sovereignty. See Regina v. Secretary of State for Foreign and Commonwealth Affairs, ex parte Lord Rees-Mogg, Divisional Court (1993), Oppenheimer I, p. 911. As far as the new members are concerned, see the Polish Constitutional Tribunal's judgment on the Lisbon Treaty, supra note 50, para. 2.2.

56 It is a characteristic feature of the decisions of the French Conseil Constitutionnel. See supra notes 10 and 46. It is also well grounded in the judiciary of other national courts, including the new Member States. See e.g. the judgment of the Polish Constitutional Tribunal on the European Arrest Warrant of 27.4.2005, P 1/05, para. III. 5.7.

57 F.C. Mayer, The European Constitution and the Courts. Adjudicating European Constitutional Law in a Multilevel System, 'Jean Monnet Working Paper', 9/2003, http:// www.jeanmonnetprogram.org/papers/03/030901-03.pdf, pp. 34-36, where the author speaks of the 'frictional phenomena'.

58 It is particularly emphasised by the German Constitutional Court. See Solange I, supra note 45; Solange II, supra note 45; Banana Market Organization Constitutionality case (2000), BVerfG 102, 147; BVerfG 2 BvR 2236/04 European arrest warrant case; BVerfG 2 BvE 2/08 Lisbon Treaty case. See also the judgments of other constitutional and supreme courts: Spa Granital, supra note 47; Fragd v. Amministrazione Delle Finanze Dello Stato case (1989), Oppenheimer I, pp. 653, 657; Frontini, supra note 47 (Italy); 
aspire to control the activities of the EU and its bodies within conferred competences. The decisions of the BVerfG concerning the constitutionality of the Maastricht Treaty, European Arrest Warrant and the Lisbon Treaty ${ }^{59}$ are well known as a spectacular manifestation of this tendency. But this approach is seen by some scholars as unfounded under European law. One of the commentators estimated the German Constitutional Court decision of 2005 on the European arrest warrant as follows: "[T]he Court simply ignores [...] that after this decision, pending new legislation, Germany is in breach of European law obligations". ${ }^{60}$

The stand point of the Bundesverfassungsgericht was shared by the Polish Constitutional Tribunal in the Accession Treaty case of 2005 and the Lisbon Treaty case of $2010 .^{61}$ In both judgments, the Tribunal remarked that the principle of interpreting domestic law in a manner "sympathetic to European law", as formulated within the Constitutional Tribunal's jurisprudence, had its limits. It repeated the position of the Polish Constitution as the "supreme law of the State" (Article 8(1)) and strongly emphasised that the Polish Constitutional Tribunal is the only arbiter of constitutionality of law binding in Poland. In the Accession Treaty judgment, it stated:

"The Member States maintain the right to assess whether or not, in issuing particular legal provisions, the Community (Union) legislative organs acted within the delegated competences and in accordance with the principles of subsidiarity and proportionality. Should the adoption of provisions infringe these frameworks, the principle of the precedence of Community law fails to apply with respect to such provisions."

Aepesco case (1991), Oppenheimer I. pp. 705, 706 (Spain); Carlsen et al. v. Rasmussen, note 55 (Denmark). See F. Mayer, supra note 57, at 29-32. Such reservations were also raised by the Spanish Constitutional Court in Statement no. 1/2004 of 13.12.2004 where the Court stated that "the powers the exercise of which is transferred to the European Union could not, without a breach of the Treaty itself, be used as grounds for the European rulemaking the content of which would [be] contrary to the fundamental values, principles, or rights of our Constitution". Quoted after Ricardo Alonso Garcia, The Spanish Constitution and the European Constitution: The Script for a Virtual Collision and Other Observations on the Principle of Primacy, 'German Law Journal' 2005, p. 1001, 1012. Those reservations were also clearly raised by the Polish Constitutional Law in the Accession Treaty judgment of 2005 and the Lisbon Treaty judgment of 2010 (supra note 50).

59 Supra notes 55 and 58.

60 F. Mayer supra note 8, p. 90.

61 Supra note 50. 
It seems that the approach of national courts to the interpretation of the primacy principle given by the CJEU is decisive for determining whether the CJEU's view on the primacy issue really shapes European legal space. The national constitutional and supreme courts do not entirely share the Luxembourg Court's interpretation of the principle, because the latter, according to them, has no power to shape the national constitutional principles. As Bruno de Witte puts it:

"The national courts [...] see EU law as rooted in their constitution and seek a foundation for the primacy and direct effect of EU law in that constitution. [...] One could argue [...] that attributing State powers to international institutions is one thing, and deciding upon the domestic effect of rules adopted by such institutions (and rules contained in the Treaty creating the institutions) is quite a different thing." ${ }^{2}$

These are the 'attribution of powers' given in constitutional clauses that set the limits of the penetration of EU law in domestic legal orders. The national constitutional and supreme courts accept the role allocated to them by the CJEU only to some extent. Their acceptance is selective and based in fact on the national courts' own constitutional terms and conditions. Besides, we must remember about the procedural autonomy of the Member States, as this still matters. This is why the effectiveness of EU norms is being shaped by the pre-existing structure of the national legal orders, and the CJEU should not and cannot perform the function of 'arbiter of the constitutionality of law' within the national legal space. Notably, BVerfGR has not only appeared to be reluctant to accept the unconditional primacy of European law but has also contested the authority of the Luxembourg Court. ${ }^{63}$ Thus, for national constitutional courts, national constitutions really matter, and they are the guardians of them. There is another conclusion following from the decisions of national judicial bodies. It concerns the overall nature of EU law. Though this law has some unique features, it does not cease to be a branch of international law founded on the consent of the Member States acting on the basis of constitutional entitlement.

63 BVerfG 89, 155, Maastricht Treaty Case, supra note 55. See comment on this famous judgment by G. Beck, The Problem of Kompetenz-Kompetenz: A Conflict between Right and Right in Which There Is No Praetor, 'European Law Review' 2005, vol. 30, pp. 42, 52-67. 


\section{Critical look at the Luxembourg Court's interpretation of the primacy principle and its judicial power}

From the standpoint of material sources of law, the Union legal order and constitutional legal orders of the Member States constitute complementary sets of the legal norms and values embodied in them, which enables us to speak of 'European monism'. After all, the fundamental values of the EU "are common to the Member States" (Article 2 of the Treaty on the EU). This mutual link is called 'constitutional pluralism', 'European legal pluralism',' 'multicentrelegal system',66 'multilevel constitutionalism' (Verfassungsverbund) ${ }^{67}$ or 'European unwritten social contract, ${ }^{68}$ the result of which is an unwritten EU constitution or basic law coordinating the operation of national law systems. It is emphasised that in such an approach to the relationship between a presumptive European constitution and national constitutional orders, the hierarchy of sources of law is challenged, whereby the problem of supremacy regarding EU law and State constitutions ceases to be the most important one. As a result, the concept of supremacy (Geltungsvorrang) is rejected in favour of the concept of primacy in application (Anwendungsvorrang). Likewise, instead of 'hierarchy' in the European legal space, it is sometimes said that the relationship between the EU and national legal orders remains a 'heterarchical' one. This is what is called a 'new legal pluralism'. Indeed, the CJEU has used neither the notions 'superior legal order' and 'inferior legal order' nor the concept of 'supremacy' to emphasise the primacy of EU acts, although these notions have been used by national courts.

64 N. MacCormick, The New..., supra note 33, p. 42.

65 M.P. Maduro, Europe and the Constitution: What if This Is As Good As It Gets?, [in:] J.H.H. Weiler \& M. Wind (eds.), supra note 5, pp. 98-101; A. Albi \& P. van Elsuwege, supra note 38 , p. 742.

${ }_{66}$ E. Łętowska, Multicentryczność współczesnego systemu prawa i jej konsekwencje [Multicentrality of the modern legal system and its consequences], 'Państwo i Prawo' 2005, nr 4, p. 3.

67 I. Pernice, Multilevel Constitutionalism in the European Union, 'Whi-Paper' 2002/2, http://www.whi-berlin.de/pernice-constitutionalism.htm; F.C. Mayer, supra note 57.

68 P. Allott, The Health of Nations: Society and Law beyond the State, CUP, Cambridge 2002, p. 179. 
However, the principle of primacy as a part of what is called 'European legal pluralism' should not be explained under EU law only. Such an approach would depreciate the national legal orders and would thereby challenge the legal pluralism itself. After all, the latter assumes a mutually amicable relationship between national laws and EU law, and multiplicity lies at the heart of European integration. This is why the traditional point of view spread between monism and dualism still seems important, and it should not be receded into the background. It follows that the EU constitutional provisions concerning mutual relations between the EU and the Member States should be regarded as a whole. In this interpretation, the primacy principle cannot be considered in isolation from another basic principle of EU law - the principle of conferral of competences. Article 5 of the Treaty on the EU states:

"1. The limits of Union competences are governed by the principle of conferral. The use of Union competences is governed by the principles of subsidiarity and proportionality. 2. Under the principle of conferral, the Union shall act only within the limits of the competences conferred upon it by the Member States in the Treaties to attain the objectives set out therein. Competences not conferred upon the Union in the Treaties remain with the Member States."

From the principle of conferred powers, it follows that every binding European act must be based on a grant of legitimate power. At the same time, the procedure for the adoption of every act determines the scope of the formal input of each of the principal institutional actors, including the Member States. Failure to respect that procedure violates the balance of powers between the institutions, and/or that between the EU and the Member States, intended by the Treaties, while failure to respect the limits of the competence derived from a particular legal basis infringes upon the principle of conferred powers itself. ${ }^{69}$ This is why the Luxembourg Court proclaimed in its Opinion on the Biosafety Protocol of 2001 that the "choice of the appropriate legal basis has constitutional significance". ${ }^{70}$

According to the conferral principle, the Member States remain 'the masters of the Treaties', because they possess Kompetenz-Kompetenz,

69 K. St C. Bradley, Powers and Procedures in the EU Constitution: Legal Bases and the Court, [in:] P. Craig, G. De Búrca (eds.), supra note 4, p. 86.

70 Opinion 2/00 ECLI:EU:C:2001:664, para. 5. 
within which they define their own competences and those of the Union. ${ }^{71}$ Viewed from this perspective, the grounds for the primacy of EU law do not stem from the presumptive autonomous nature of Community/EU law but from its international legal origins, i.e. from the consent of the Member States which entails unambiguous consequences in international law. At first sight, one can argue that the connection of the primacy principle with the conferral principle weakens the significance of the former, since it clearly indicates the limits of the primacy of European law.

In light of the pacta sunt servanda principle, the explicit establishment of the principle of EU primacy in the former Constitutional Treaty was not a new quality, because an implied clause of primacy, even supremacy over national law, is contained in every international agreement. EU law, like earlier the law established by the EEC Treaty, is simply related to the traditional rule pacta sunt servanda. As such, it has not ceased to be international law, and the primacy principle does not set EU law apart from the general body of international law. ${ }^{72}$

Furthermore, there is a strong opposition of the national courts against unlimited acceptance of the primacy of Community/EU law, which arose with particular intensity in the States that rejected the 'European monism' represented by the CJEU. As discussed in Part III of the paper, the national courts have mostly accepted the dualist approach of implementation of international law in the national sphere and have applied mutatis mutandis this approach to determine the relations between national law and European law. Thus, the CJEU's interpretation of the primacy of European law based on its autonomy and direct effect and separation from the body of international law seems to be disputable. It is

71 The importance of the conferral principle has also been stressed by the CJEU despite its pro-Community approach. In particular, the CJEU opposed the infringement of the conferral principle through too great a latitude in interpreting the flexibility clause from Article 308 (ex Article 235) of the Treaty establishing the European Community. See Accession by the Community to the European Convention for the Protection of Human Rights and Fundamental Freedoms, Opinion of the Court of 28.3.1996, ECLI:EU:C:1996:140, para. 4. On the issue of Kompetenz-Kompetenz and significance of the conferral principle within it, see e.g. G. Beck, supra note 63.

72 B. De Witte, supra note 4, p. 361. But $c f$ the following view by Franz Mayer: "[I]t is more fruitful to explain European integration in constitutional law terms, and not in public international law terms [...] [L]ooking at the issue in this way is motivated by the Rechtsgemeinschaft - view on European integration, which is quite distinct from a public international law approach or a sovereign-driven approach". F.C. Mayer, supra note 8, p. 94. 
only the judicial control held by the CJEU that creates the unique feature of EU law. In most other international judicial or quasi-judicial systems, there is no direct link between the international court and national courts, making it much more difficult to coordinate legal interpretation across boundaries. As Karen Alter states: "Replicas of the ECJ do exist, but it is still largely true that these systems are unable to create serious domestic political costs for ignoring an international court ruling." ${ }^{73}$

It is hardly to be convinced by the view that the primacy principle supports a process of identification of EU citizens with the European Treaties as their common supreme law. ${ }^{74}$ This view should be regarded as wishful thinking. Most people still identify themselves with a national constitution, because they do not live 'beyond the State' yet. It is questionable, therefore, to assert that sovereignty shifts from the Member States to European $\operatorname{demos}^{75}$, and the judicial constitutional power shifts from the national courts to the Luxembourg Court. Thereby, one can argue for an existing informal European constitutionalism which is just being shaped and still remains rather unclear. At any rate, it is not built 'beyond the State' as some scholars claim ${ }^{76}$ but by the Member States and for their societies.

73 K.J. Alter, supra note 7, p. 136. Alter speaks of eight other international legal systems that copy the CJEU design of a preliminary ruling mechanism. Actually, there is just one exception similar to the Luxembourg Court's judicial power, namely, the system of the European Court of Human Rights.

74 It is advanced by K. Lenaerts \& D. Gerard, The Structure of the Union according to the Constitution for Europe: the Emperor Is Getting Dressed, 'European Law Review' 2004 vol. 29, pp. 289, 301.

75 Thus argued, e.g., by A. Verhoeven, The European Union in Search of a Democratic and Constitutional Theory, Kluwer Law International, The Hague 2002 p. 292; A. Albi \& P. van Elsuwege, supra note 38, pp. 755-759.

${ }^{76}$ Quite symptomatic here seems to be the title of the well-known book edited by J. Weiler \& M. Wind. See, supra note 5. 


\section{The Limits of the Primacy Principle under the International Legal Status of the Member States and their Consequences for the 'Ultimate Arbiter' Controversy}

In its famous judgments on the Maastricht Treaty and Lisbon Treaty cases ${ }^{77}$, the German Federal Constitutional Court stressed inter alia the sovereign status of Germany as a Member State. The BVerfG used the well-known term to denote the EC/EU Member States as 'the masters of the Treaties', and the European Union was characterised as a 'treaty union of sovereign States'. The sovereign status of the Member States has also been emphasised by the courts of other members. ${ }^{78}$ These views reflect the actual international legal status of the Member States despite the frequent and even fashionable tendency in the present-day theory of international and European law to challenge the importance of State sovereignty, or at least to considerably relativize it. By means of new conceptual constructs, the legal doctrine strives to explain the unprecedented widespread fact of interdependence in exercising State functions by the Members within the EU. Thus, the concepts of 'post-sovereignty' ${ }^{79}$ and 'sovereignty beyond the State ${ }^{80}$ are used. A view has even been expressed that there "simply is no nucleus of sovereignty that the Member States can invoke, as such, against the Community" ${ }^{81}$ Contrary to that, however, the present author could follow the view of the national constitutional courts stating that the old concept of sovereignty - despite its ambiguity - can still be a good means for analysing the legal status of the Member States. As such, this view influences the problem of an 'ultimate arbiter'.

77 Maastricht Treaty 1992 Constitutionality case, supra note 55; Lisbon Treaty case, supra note 58, para. 336 and 339. See also the earlier judgment on the Kloppenburg case, supra note 45 .

78 See e.g. the Danish Supreme Court's Carlsen et al. v. Rasmussen case, supra note 55; the Spanish Constitutional Court's Statement no. 1/2004, supra note 58; the Polish Constitutional Tribunal's judgments on The Accession Treaty, supra note 50, and especially on the Lisbon Treaty, supra note 50, para. III.2.1, III.2.2, III.3.8.

79 N. MacCormick, Questioning Sovereignty..., supra note 33, pp. 132-142.

80 P. Allott, supra note 68, pp. 176-179. See also A. Abbi \& P. van Elsuwege, supra note 38 , passim.

81 K. Lenaerts, Constitutionalism and the Many Faces of Federalism, 'American Journal of Comparative Law' 1990, vol. 38, pp. 205, 220. 
It is obvious that the EU Members have not ceased to be States, instead retaining their identity under international law. ${ }^{82}$ Thereby, they still remain 'the masters of the Treaties'. Accordingly, the view that the unique polity created by the European Treaties is a 'constitutional order of States' seems to be well founded. ${ }^{83}$

The CJEU has consistently emphasised the "permanent limitation of sovereign rights" of the Member States, without, however, giving specific reasons for this thesis. ${ }^{84}$ On the other hand, there is a similar, that is non-grounded enough approach to sovereignty before national courts. There are even decisions where we could find two mutually contradictory understandings of sovereignty. ${ }^{85}$ Therefore, it appears justifiable to approach the question of State sovereignty with caution and refrain from hasty judgments in this respect, at least until one can establish, consistently rather than arbitrarily, what sovereignty is today.

The phenomenon of interdependence is treated with caution by the Member States themselves. Indeed, it is a very fragile issue for the Member States. For example, the 'Decision of the Heads of State or Governments concerning certain problems raised by Denmark on the Maastricht Treaty on European Union' of 11-12.12.1992 asserted that the Treaty on the European Union "involves independent and sovereign States having freely decided, in accordance with the existing Treaties, to exercise in common some of their competences". ${ }^{86}$ Of significance in this field is

82 See A. Dashwood, States in the European Union, 'European Law Review' 1998, vol. 23, pp. 201, 202; R. Kwiecień, Sovereignty of the European Union Member States: International Legal Aspects, [in:] A. Bodnar et al. (eds.), 'The Emerging Constitutional Law of the European Union - German and Polish Perspectives', Springer, Berlin-Heidelberg 2003, pp. 339, 351-354; C. Mik, State Sovereignty and European Integration: Public International Law, EU Law and Constitutional Law in the Polish Context, [in:] N. Walker (ed.), 'Sovereignty in Transition', Hart, Oxford-Portland 2003, pp. 367, 378-383.

83 A. Dashwood, [in:] Wyatt \& Dashwood's European Union Law, $4^{\text {th }}$ ed., Hart, Oxford-Portland 2000, p. 151.

84 See e.g. Opinion of the Court of 14.12.1991 on Draft agreement between the Community, on the one hand, and the countries of the European Free Trade Association, on the other, relating to the creation of the European Economic Area, ECLI:EU:C:1991:490, para. 21.

${ }^{85}$ See e.g. the judgment of the Irish Supreme Court on the Crotty case, supra note 44.

86 A.G. Harryvan \& J. Van Der Harst (eds.), Documents on European Union, McMillan, London 1997, pp. 285-286. Today, a similar presentation of the problem can be found in the French Constitution of 1958. Its Article 88(1) states: "La République 
also Article 5(2) of the Treaty on the European Union speaking about conferring competences to the EU by the Member States "to attain objectives they have in common". One could speak about limiting the sovereignty of the EU Members, assuming that sovereignty is a sum of State competences. This interpretation of sovereignty cannot, however, find its justification in international law. In the case law of international courts, there is an established and well-grounded view that the capacity to undertake international obligations that even permanently shape the exercise of State functions is a manifestation rather than limitation of sovereignty. ${ }^{87}$ In international law, sovereignty is the State's complete capacity to define the forms in which its functions are exercised ${ }^{88}$ This is why the primacy of Union law in the domain of conferred competences is fully justified, because it stems from mutual international obligations undertaken by the Member States. On the other hand, the exceeding by EU bodies of the limits of conferred competences suspends the operation of the primacy principle. Therefore, an important issue in European primary law is the division of competences between the Member States and the EU. This proves that the Member States still remain the principal lawmakers in the area of European integration.

Moreover, the EU's duty to respect the nucleus of statehood of its members confirmed by the Treaty on the EU should be taken into account:

"The Union shall respect the equality of Member States before the Treaties as well as their national identities, inherent in their fundamental structures, political and constitutional, inclusive

participe à l'Union européenne constituée d'États qui ont choisi librement d'exercer en commun certaines de leurs compétences en vertu du traité sur l'Union européenne et du traité sur le fonctionnement de l'Union européenne, tels qu'ils résultent du traité signé à Lisbonne le 13 décembre 2007".

${ }^{87}$ It is especially worth noting the first judgment of the Permanent Court of International Justice in the Wimbledon case (Great Britain et al. v. Germany), 1923 P.C.I.J. (ser. A) No. 1, p. 25.

${ }^{88}$ Such an understanding of State sovereignty is justified broadly, e.g. by J. Crawford, Sovereignty as a Legal Value, [in:] J. Crawford, M. Koskenniemi (eds), 'The Cambridge Companion to International Law', CUP 2012; J. Crawford, Chance, Order, Change: The Course of International Law, The Hague 2014, pp. 86-114; J. Kranz, Réflexions sur la souveraineté, [in:] J. Makarczyk (eds.), 'Theory of International Law at the Threshold of 21 ${ }^{\text {st }}$ Century', Kluwer Law International, The Hague 1996, p. 183; R. Kwiecień, Does the State still Matter? Sovereignty, Legitimacy and International Law, 'Polish Yearbook of International Law' 2012, vol. 32, p. 45. 
of regional and local self-government. It shall respect their essential State functions, including ensuring the territorial integrity of the State, maintaining law and order and safeguarding national security. In particular, national security remains the sole responsibility of each Member State" (Article 4(2)).

There are clear analogies between the provision of Article 4(2) of the EU Treaty and the provisions of the United Nations Charter. The equality of the EU Members before the Treaty corresponds to the principle of sovereign equality of the Charter's Article 2(1). The duty of the Union to respect national identities and fundamental State functions or functions that international law attaches to the nature of statehood corresponds in turn to the provision of Article 2(7) of the UN Charter. National identity is a core issue as far as the 'ultimate arbiter' problem is concerned, because national identity includes constitutional identity. What is more, national identity, as argued by the Polish Constitutional Tribunal in the Lisbon Treaty judgment, cannot exist without constitutional identity. The latter, according to the Tribunal, is tantamount to State sovereignty, and sovereignty is confirmed and protected in the European Treaties by the principle of conferral competences. ${ }^{89}$

Could Article 4(2) be seen as a starting point or fierce limit on the European level to revoke the claim of primacy of European law over the Member States' constitutional identity? And a more crucial question: who decides upon this limit? Should integrity and identity of the European order or the national order be stronger protected? If the European legal order, it is the CJEU that performs the role of the final arbiter of constitutionality in Europe. One would argue that such a conflict would have to be solved within the system, which points to the CJEU. ${ }^{90}$ This is the obligation flowing from the European treaties, which is an international legal obligation. But if the national legal orders still mater, the conflict would have to be solved by the national constitutional court. Tertium non datur. And if the conflict between the national legal order and the European legal order cannot be resolved, the Member States can do what was pointed out by the Polish Constitutional Tribunal in its judgment on the Accession Treaty, i.e. leaving the Union. Withdrawal from the Union would definitely conclude the 'ultimate arbiter' controversy between the CJEU and a given national constitutional court.

89 The Lisbon Treaty case, supra note 50, para. III.2.1 and III.2.2.

90 F. Mayer, supra note 8, p. 96. 
Articles 4 (1) and 5 (1-2) of the EU Treaty concerning the conferral principle establish the 'domain reserved' resulting from international law, which seems to be exempt from appraisal by the European courts and other agencies of the EU. These provisions embody values that are constitutive for the legal nature of States as sovereign subjects. Due to this sovereign nature, it is the EU Members that confer competences on the Union and not the other way round. Moreover, an argument from legal certainty should be put forward here, namely, it must be the national constitutional courts who, when called upon, have the right to determine the limits of the transferred powers to the Union. ${ }^{91}$ It follows that it should be the national constitutional courts and not the CJEU who are the ultimate arbiters over the limits of the EU's competences. The values that make up the legal status of the Member States cannot be interfered with by Union law. This is why they are excluded from the primacy of this law. ${ }^{92}$ The legal acts of the European Union aimed at the fields referred to in Articles 4(1) and 5(1-2) would certainly be ultra vires acts, for they would not find justification either in the light of the national constitutions or international law, especially the European Constitutional Treaties alone. On the other hand, however, the international legal duty to observe EU law is indisputable, and it has nothing to do with State sovereignty. But an argument for sovereignty has been recently praised by the Polish Parliament during the European debate on so-called 'judicial reform' and the rule of law in Poland..$^{93}$ The rule of law, however, is one of the fundamental values on which the EU is founded. As such, it is covered by the Union's competence.

\section{Conclusions Arising from the Conflict over "The Final Arbiter of Constitutionality" within the EU}

The controversy between the constitutional and supreme national judicial organs and the CJEU proves, first of all, that both parties have kept their

92 Such a position was directly emphasised by the Polish Constitutional Tribunal in the Accession Treaty case and Lisbon Treaty case, supra note 55.

93 See a resolution of the Polish Sejm of 20.5.2016 w sprawie obrony suwerenności Rzeczypospolitej Polskiej i praw jej obywateli [On the defence of sovereignty of the Republic of Poland and the rights of its citizens], Monitor Polski, 2016, item 466. 
autonomy in their jurisdictional domains. There is no coercive judicial authority in the European legal space because of, as Stone Sweet puts it, "the absence of normative authority" ${ }^{94}$ This also challenges the thesis about the subordination of national law to EU law. Despite the close connections between them, they do not remain within the realm of supremacy. In this sense, European integration does undermine the hierarchical understanding of the law. ${ }^{95}$ The national legal orders and the EU legal order have their own hierarchy of norms, and, although they have influenced each other and partially overlap, each ultimately retains its own rule of recognition. ${ }^{96}$

In the present state of legal relations between the EU and the Member States, the issue of primacy/supremacy remains, in fact, insoluble, because there is no arbiter within the European legal space. ${ }^{97}$ Consequently, the postulates that demand changes in the constitutional provisions stressing the supremacy of the national constitution in the Member States are unfounded. The constitutions of the EU Member States did not and, as long as the EU Members retain the status of States or sovereign subjects of international law, will not occupy a lower position in the hierarchy of sources of law than the Union provisions. For as long as the States retain the position of subjects vested with Kompetenz-Kompetenz, certain constitutionally protected values will be exempt from the operation of the principle of primacy of EU law. ${ }^{98}$ On the other hand, however, the international legal obligation of the Member States to observe EU law is indisputable. As Franz Mayer states:

"[U]nilaterally reshaping primacy from a Member State position is not admissible; as such unilateral action undermines the very basis

94 A. Stone Sweet, The Juridical..., supra note 7, p. 927.

95 Cf M.P. Maduro, supra note 65, pp. 95-96.

96 G. Beck, supra note 63, p. 67.

97 J. Frowein observed in this context: 'As long as the Community system has not developed into a federal structure, questions of sovereignty or final priority as to sources of law have to be kept in suspense,' J. A. Frowein, Solange II, 'Common Market Law Review' 1988, vol. 25, pp. 201, 204. See also G. Beck, supra note 63, p. 67, who underlines that "the issue of Kompetenz-Kompetenz is part of the resultant catalogue of unanswered questions" and concludes: "If they (national and European legal systems - R.K.) come into conflict, their relation can only be one of right against right, a conflict in which there can be no praetor" (p. 67).

98 C.U. Schmid, The Neglected Conciliation Approach to the 'Final Arbiter' Conflict, Common Market Law Review 1999, vol. 36, pp. 509, 512; Kumm/Comella, supra note 8, p. 24. 
of the functioning of European law: trust into the reciprocal obedience to European law. This is a simple issue of legal obligations; thus, it has nothing to do with sovereignty of the Member States". ${ }^{9}$

Therefore, it would be inappropriate to say that European legal norms occupy a position below the provisions of national law. The basic obligation of the State is to take actions in this area by the legislative and executive and judicial authorities, which will ensure the effectiveness on its territory of provisions adopted under international obligations. Such actions are meant to protect the inviolability of the presumption of compatibility of national law with EU law. This presumption allows for a mutually amicable interpretation. Taking into account, however, the possibility of the EU's legal actions outside conferred competences, the national court can be confronted with the difficult dilemma: whether to refuse to apply EU law (which was supported e.g. by the Bundesverfassungsgericht, the Conseil Constitutionnel and the Polish Constitutional Tribunal) or start the procedure by the State of invalidation of a European measure before the CJEU. The former solution is difficult to accept from the standpoint of European law, since it contains its own mechanisms for solving problems of this type, which is strongly and legitimately supported by the CJEU case law and accepted by the Member States themselves. The latter solution may raise doubts in light of the constitutional provisions of the Member States, insofar as an international agency has exceeded the constitutional limits on its action within the State. At first sight, the proposal to establish a neutral institution of a judicial or quasi-judicial nature, authorised to express opinions in the event of a constitutional conflict within the EU, seems to be interesting and useful. ${ }^{100}$ But is this possible in practice? What would be a legal foundation for this? In particular, different than a treaty, that is international law?

Although the entry into force of a new constitutional reform, i.e. the Lisbon Treaty, has not concluded the 'ultimate arbiter of constitutionality' controversy, a significant advantage of the Treaty appears to be the delimitation of limits within which the principle of primacy of EU law operates. At issue is the protection of competences of the Member

99 F. Mayer, supra note 8, p. 90. F.Mayer underlines that "this is not well understood" in decisions of the Polish and German Constitutional Courts.

100 See C.U. Schmid, supra note 99, pp. 513-514; F.Mayer, supra note 8, pp. 38-40 (and literature on the subject given therein). 
States, crucial for their international legal status against any EU action not founded in the conferral principle.

The conferral principle and the EU's obligation to respect the nucleus of statehood of its Members set more stable limits for the primacy principle after the Lisbon reform, which surely underlines the position of the EU Members as the 'masters' of the European Constitutional Treaties. This context forms a barrier against the 'Europeanisation' of national law, without legitimacy recognised by this law. It follows that within the jurisdictional areas of the Member States, their constitutional/supreme courts act as 'arbiters of constitutionality'. But on the other hand, such a role is fulfilled by the CJEU within European law. Thus, the national courts and the CJEU are independent judicial bodies in their capacities. This is why they are nolens volens institutional guardians of the "European legal pluralism'.

\section{Bibliography}

1. Albi A.\& van Elsuwege P., The EU Constitution, National Constitutions and Sovereignty: An Assessment of a "European Constitutional Order", 'European Law Review' 2004, vol. 29.

2. Alter K. J., The European Court's Political Power. Selected Essays, OUP, Oxford 2009.

3. Beck G., The Problem of Kompetenz-Kompetenz: A Conflict between Right and Right in Which There Is No Praetor, 'European Law Review' 2005, vol. 30.

4. Boulouis J., Chevallier R.M., Grands Arrêts de la Cour de Justice des Communautes Européennes, $6^{\text {th }}$ ed., vol. I, Dalloz-Sirey, Paris 1994.

5. Bradley K. St C., Powers and Procedures in the EU Constitution: Legal Bases and the Court, [in:] P. Craig, G. De Búrca (eds.), 'The Evolution of EU Law', 2nd ed., OUP 2011.

6. Crawford J., Sovereignty as a Legal Value [in:] J. Crawford, M. Koskenniemi (eds), 'The Cambridge Companion to International Law', CUP 2012.

7. Dashwood A., States in the European Union, 'European Law Review' 1998, vol. 23.

8. Frowein J.A., Solange II, 'Common Market Law Review’ 1988, vol. 25.

9. Jacobs F.G., The Sovereignty of Law. The European Way, CUP, Cambridge 2007.

10. Kowalik-Bańczyk K., Should We Polish It Up? The Polish Constitutional Tribunal and the Idea of Supremacy of EU Law, 'German Law Journal' 2005, no. 10.

11. Kumm M. \& Ferreres Comella V., The Future of Constitutional Conflict in the European Union: Constitutional Supremacy after the Constitutional Treaty, 
'Jean Monnet Working Paper' 5/04, http://www.jeanmonnetprogram.org/ papers/04/040501-15.pdf.

12. Kumm M. \& Ferreres Comella V., The Primacy Clause of the Constitutional Treaty and the Future of Constitutional Conflict in the European Union, 'ICON' 2005, vol. 3. p. 1479.

13. Kwiecien R., The Primacy of European Union Law over National Law under the Constitutional Treaty, 'German Law Journal. Special Issue - Unity of the European Constitution' 2005 , no. 11.

14. Lenaerts K., Constitutionalism and the Many Faces of Federalism, 'American Journal of Comparative Law' 1990, vol. 38.

15. Lenaerts K. \& Gerard D., The Structure of the Union according to the Constitution for Europe: the Emperor Is Getting Dressed, 'European Law Review' 2004, vol. 29.

16. Łętowska E., Multicentryczność wspótczesnego systemu prawaijejkonsekwencje, 'Państwo i Prawo' 2005, no. 4.

17. MacCormick N., The New European Constitution. Legal and Philosophical Perspective, Biuro Trybunału Konstytucyjnego, Warsaw 2003.

18. MacCormick N., Questionning Sovereignty: Law, State and Nation in the European Commonwealth, OUP, Oxford 1999.

19. Maduro M.P., Europe and the Constitution: What if This Is As Good As It Gets?, [in:] J.H.H. Weiler \& M. Wind (eds.), 'European Constitutionalism Beyond the State', CUP, Cambridge 2003.

20. Mayer F.C, Europarecht als französisches Verfassungsrecht, 'Europarecht' 2004, no. 6

21. Mayer F.C., The European Constitution and the Courts. Adjudicating European Constitutional Law in a Multilevel System, 'Jean Monnet Working Paper', 9/2003, http://www.jeanmonnetprogram.org/papers/03/030901-03.pdf.

22. Mayer F.C., Supremacy lost? - Comment on Roman Kwiecien, 'German Law Journal. Special Issue - Unity of the European Constitution' 2005, no. 11.

23. Mik C., State Sovereignty and European Integration: Public International Law, EU Law and Constitutional Law in the Polish Context, [in:] N. Walker (ed.), 'Sovereignty in Transition', Hart, Oxford-Portland 2003.

24. Pernice I., Multilevel Constitutionalism in the European Union, 'Whi-Paper' 2002/2, http://www.whi-berlin.de/pernice-constitutionalism.htm.

25. A Pre-emptive Strike from the Palais Royal, Editorial, 'European Law Review' 2005, vol. 30.

26. Schilling T., The Autonomy of the Community Legal Order: An Analysis of Possible Foundations, 'Harvard International Law Journal' 1996, vol. 37.

27. Schmid C.U., The Neglected Conciliation Approach to the 'Final Arbiter' Conflict, 'Common Market Law Review' 1999, vol. 36.

28. Stone Sweet A., The European Court of Justice, [in:] P. Craig, G. De Búrca (eds.), 'The Evolution of EU Law', 2nd ed., OUP 2011.

29. Stone Sweet A., The Judicial Construction of Europe, OUP, Oxford 2004. 
30. Stone Sweet A., The Juridical Coup d'État and the Problem of Authority, 'German Law Journal' 2007 no. 10.

31. Verhoeven A., The European Union in Search of a Democratic and Constitutional Theory, Kluwer Law International, The Hague 2002.

32. Weiler J.H.H., In Defense of the Status Quo: Europe's Constitutional Sonderweg, [in:] J.H.H. Weiler \& Marlene Wind (eds.), 'European Constitutionalism Beyond the State', CUP, Cambridge 2003.

33. Weiler J.H.H. \& von Bogdandy A., Doctrine of Principles, 'Jean Monnet Working Paper' 2003, 9/03, http://jeanmonnetprogram.org/ papers/03/030901-01.pdf.

34. Weiler J.H.H \& Haltern U.R., Autonomy of the Community Legal Order Through the Looking Glass, 'Harvard International Law Journal' 1996, vol. 37.

35. De Witte B., Direct Effect, Primacy and the Nature of the Legal Order, [in:] P. Craig, G. De Búrca (eds.), 'The Evolution of EU Law', 2nd ed., OUP 2011.

36. De Witte B.,"Retour à Costa". La primauté du droit communautaire à lumière du droit international, 'Revue Trimestrielle de Droit Européen' 1984, no. 20.

37. Wouters J., National Constitutions and the European Union, 'Legal Issues of Economic Integration' 2000, no. 27. 